\title{
Europskost ukidanja praznika i socijalističkog neradničkog mentaliteta
}

\author{
MATEJA HABINC \\ Odsjek za etnologiju i kulturnu antropologiju \\ Filozofski fakultet, Sveučilište u Ljubljani
}

\begin{abstract}
U tekstu se analiziraju službeni i neslužbeni diskursi (medijsko izvještavanje, internetski komentari i forumi) u Sloveniji i Hrvatskoj koji ukidanje praznika tematiziraju kao gospodarsku mjeru (štednje). Prate se odnosi između ukidanja praznika, marljivosti i mentaliteta na jednoj strani te balkanskog, socijalističkog i europskog identiteta na drugoj. Prikupljena građa sugerira da su obje vlade prijedlozima o ukidanju praznika potakle većinom dvije vrste komentara: o povezanosti praznika s marljivošću i o tome koje bi praznike i uz njih vezane identitete eventualno valjalo ukinuti. Većina neslužbenih diskursa praznike uglavnom nije povezivala s produktivnošću, niti se fokusirala na sustavno uređenje plaćanja rada za vrijeme praznika (i/ili neradnih dana) i radnička prava. Znatno više komentara posvećeno je pojmu socijalističkog mentaliteta, navodno povezanog s pojedinačnim praznicima, pri čemu se produktivnost, u manjoj mjeri nego približavanje Europi, pokazala ciljem predloženih (i/ili realiziranih) sustavnih promjena.
\end{abstract}

Ključne riječi: praznici, štednja, mentalitet, bivša Jugoslavija, (post)socijalizam

Kao što je već sredinom osamdesetih godina prošlog stoljeća utvrdio Vilko Novak, proučavanje nacionalnih karakteristika u slovenskoj etnologiji rijetko je bilo predmetom istraživanja budući da etnolozi to područje prepuštaju psihologiji, koja "ga također izbjegava" (Novak 1986: 35). Unatoč tome, važne dokumente na tom području pružili su Franjo Baš i Anton Trstenjak (Baš 1965; Trstenjak 1991), no smatra se da "iako su ti i neki drugi prikazi nacionalnih karakteristika zasnovani na sustavnom promatranju ili čak sustavnom istraživanju, oni ne mogu zadovoljiti stroge znanstvene kriterije" (Jezernik 1987: 32). Za to, prema Jezerniku, postoji više razloga: nisu razjašnjeni osnovni pojmovi, npr. koje bi osobine uopće trebalo uključiti u istraživanja i kako bi ih se utvrđivalo, a karakterološka istraživanja su uvijek bila više ili manje opterećena predrasudama samih istraživača, njihovim općenitim mišljenjem o obilježjima pojedinih naroda, njihovim normama i vrijednostima, pa i aktualnim društvenoekonomskim položajem te više ili 
manje raširenim etničkim stereotipovima (1987: 32-33). ${ }^{1}$ Naime, ti stereotipovi više govore o samopredodžbi zajednice i o dojmu koji zajednica ima o sebi, nego o njenoj identifikaciji (usp. Đerić 2005: 47).

Posljednjih nekoliko godina takve samopredodžbe i dojmove vezane uz nekadašnji zajednički jugoslavenski prostor odražavaju i medijske rasprave koje se tiču gospodarske situacije, štednje i s njima povezanih prijedloga ukidanja pojedinih državnih praznika. Iako proučavanje mentaliteta u posljednje vrijeme nije prominentna etnološka istraživačka tema, povezivanje pojma sa suvremenom ekonomskom situacijom te s pitanjem identiteta činilo mi se zanimljivim razlogom za dokumentiranje i analizu s time povezanih diskursa. ${ }^{2}$ Naime, kako navode Gammelgaard i Šarić, promjene kolektivnih samopercepcija i identiteta u Srednjoj i Jugoistočnoj Europi u posljednjih nekoliko desetljeća događale su se kroz različite diskurse, među ostalim i kroz one vezane uz praznike. S obzirom na kreirana i ispregovarana značenja (Gammelgaard i Šarić 2012: 16), naročito su državni praznici, kao nepostojani i promjenjivi označitelji, prikladni za analizu promjena s njima povezanih simbola i identiteta (isto: 6-7). Zbog toga u ovom prilogu analiziram internetske izvore, prije svega medijsko izvještavanje, internetske komentare i rasprave na forumima ${ }^{3}$ koji se odnose na ukidanje praznika kao gospodarsku mjeru (štednje). Analizom službenih, a još više neslužbenih diskursa kao "svakidašnjih diskursivnih praksi" koje govore o vrijednostima i osobinama nacije u svakodnevnom životu (Đerić 2005: 45/op.10), pokušala sam odnose između ukidanja praznika, marljivosti i mentaliteta dovesti u vezu s poimanjem balkanskog, socijalističkog i europskog identiteta. Time se dotičem vrednovanja i uspoređivanja socijalizma i postsocijalizma koja se, primjerice prema Markoviću, reflektiraju upravo u odnosu prema radu kao aspektu svakidašnjeg života (Marković 2007: 27), pa onda i analizom nerada i slobodnog vremena vezanog uz praznike. Posežem i za iznalascima akademskog polja koje proučava diskurse o balkanskoj regiji kao zaostaloj, primitivnoj ili, općenito, niže rangiranoj u europskoj simboličnoj geografiji (usp. Obad 2012: 7). Mada postoje mišljenja da je postkolonijalna teorija već iscrpljena i često služi kao izgovor za vječnu jadikovku i samoviktimizaciju (Todorova 2010: 178, 181, prema Obad 2012: 17), slažem se s Orlandom

\footnotetext{
${ }^{1}$ Metodološke slabosti koje utječu na nepouzdanost istraživačkih tehnika i sklonost neutemeljenom generaliziranju posljedica su nerazrađenih teorijskih polazišta. Umjesto da takva istraživanja doprinose uklanjanju predrasuda, ona ih često još više utvrđuju, a istraživanje kolektivne karakterologije je donekle validno samo ako se istodobno radi i o autorefleksiji istraživača koji ujedno problematizira vlastita polazišta (Jezernik 1987: 33).

${ }^{2}$ Istraživanje je bilo dio projekta Praznici i formiranje nacionalne zajednice u Sloveniji (Prazniki in oblikovanje nacionalne skupnosti na Slovenskem, J6-4007), koji je financirala nacionalna istraživačka agencija u razdoblju od 1. srpnja 2011. do 30. lipnja 2014.

${ }^{3}$ Izostavljam najbrojnije komentare koji se tiču osobina pojedinaca, predlagatelja ili protivnika pojedinih ideja.
} 
Obad da je ona i nadalje primjenjiva ukoliko, poput Melegha (2006), kolonijalizam razumijemo kao simbolički sustav moći te ako želimo predstaviti lokalne i regionalne diskurzivne mehanizme koji se oblikuju unutar tih odnosa (usp. Obad 2012: 24). Naime, kao što upućuje građa, isto kao i devedesetih godina prošlog stoljeća, balkanistički diskurs još uvijek je aktivan prilikom uspostavljanja unutrašnjih razlika (usp. Rihtman-Auguštin 1997, prema Obad 2012: 36). (Samo)percepcije Balkana kao graničnog, dvojnog i nepotpunog prostora (Todorova 1999: 37-40, prema Obad 2012: 16), kako ovdje želim pokazati, stvaraju se i uz pomoć suvremenog udvojenog vrednovanja socijalističke prošlosti, odnosno s njom navodno povezanog (neradničkog) mentaliteta. Slovenija i Hrvatska, na koje je usredotočena analiza, ${ }^{4}$ iako ih Todorova samo uvjetno smješta na Balkan, ${ }^{5}$ na simboličnom nivou još uvijek funkcioniraju kao samokolonizirajuća periferija s pomanjkanjem identiteta, koja nekritično i bez otpora uvozi tuđe vrijednosti i civilizacijske modele (Kiossev 1999, prema Obad 2012: 20). Ukidanjem praznika kao "socijalističkih ostataka" vlasti žele te zemlje približiti kršćanskoj Europi, dok javnost, ili barem njezin diskurzivno produktivan dio, kao krivca za nerazvijenost i različitost od Europe ne vidi ekonomske, društvene ili sustavne razloge, već najčešće "zaostali mentalitet". Pri tome, kako je to već izložila Prica, za društvenu krizu smatra se odgovornom "po mentalitetu još uvijek socijalistička većina" koja navodno vodi tranziciju u krivom smjeru, a ne i transideološka, "sposobna društvena elita" (2007: 178).

U istraživanju diskursa o praznicima, štednji i mentalitetima internet mi je služio za skupljanje podataka, što, prema Ramšak, danas predstavlja jedan od najčešćih načina upotrebe interneta u etnologiji (Ramšak 2007: 23). Uvažavajući Wittelovu opasku, napominjem da se metodološki ovdje ne radi o etnografiji interneta, nego o analizi ondje lociranih tekstova (Wittel 2004: 23), koji ne predstavljaju manje ili više točnu realnost, nego etnografsku građu koja odražava specifično razumijevanje realnosti (Hine 2004: 37). U kritičkoj analizi diskursa usredotočila sam se na odabrane teme i njihovu ulogu u konstruiranju identiteta (Gammelgaard i Šarić 2012: 23), a kako je glavna tema bila ukidanje praznika, naročito sam se fokusirala na jednu, od

\footnotetext{
${ }^{4}$ Iako su se ideje o ukidanju praznika pojavljivale i drugdje u Evropi, od svih vlada država bivše Jugoslavije, samo su vlade Slovenije i Hrvatske predlagale ukidanje državnih praznika. Na Sloveniju se referirao i istraživački projekt (vidi napomenu br. 2), pa je zato analiza fokusirana većinom na Sloveniju te komparativno i na Hrvatsku. Nije nevažno da je u vrijeme diskusije o tim pitanjima Slovenija već osam godina bila članicom Europske unije, a Hrvatska se nadala da će to skoro postati. Puno su rjeđe bile objave koje se odnose na razmišljanje o ukidanju praznika kao mjeri štednje u drugim državama bivše Jugoslavije, od kojih se ni jedna u vrijeme rasprava nije još ni nadala skorom članstvu u Europskoj uniji te zato ti medijski tekstovi nisu predmet analize.

${ }^{5}$ Zbog manjka povijesnih posljedica osmanske nadmoći Sloveniju i Hrvatsku, prema Todorovoj, samo uvjetno možemo smatrati balkanskim državama no ipak ih i sama uključuje u svoju analizu, zato što smatra da povijest Balkana u 20. stoljeću ne možemo zamisliti bez cjelovite jugoslavenske države (Todorova 1999: 62, prema Obad 2012: 35-36).
} 
inače četiri diskurzivne strategije kreiranja nacionalnih identiteta (Wodak 2006, prema Gammelgaard i Šarić 2012: 19) - onu destruktivnu, usmjerenu poništenju nekog identiteta. Dakle, u tekstu analiziram kako autori različitih internetskih tekstova razumiju one fragmente svojih života koji se odnose na njihovo slobodno vrijeme i praznike te kako ih vrednuju i s kojim identitetima i mentalitetima ih povezuju.

\section{UKIDANJE PRAZNIKA KAO GOSPODARSKA MJERA ŠTEDNJE I ODAZIV NA NJU - PRIMJER SLOVENIJE}

Od 2009. godine u Sloveniji se državnim proslavama godišnje obilježava pet praznika, ${ }^{6}$ dok su proslave koje su "osim od velikog značenja za cijelu Sloveniju blisko vezane i za određenu regiju” (STA 2012), ${ }^{7}$ organizirane samo prilikom okruglih obljetnica, tj. svakih pet godina. Zbog štednje je već tri godine kasnije odlučeno da se na državnom nivou ne slavi ni Dan otpora okupatoru niti Dan reformacije, a sva sredstva namijenjena drugim državnim proslavama vlada je smanjila za polovicu (STA 2012). Kao jedna od mjera štednje Zakonom o uravnoteženju javnih financija ukinut je i 2. siječnja kao praznik i neradni dan, dok je 2. svibnja, za koji je vlada isto tako predložila ukidanje, ostao praznik i neradni dan (Zakon o uravnoteženju javnih financ 2012). Manje od godinu dana nakon što su očekivani gospodarski učinci te mjere prema ocjenama vlade bili "pozitivni” u smislu da "nema primjetnih promjena zbog jednog ukinutog praznika" (Borko Grimšič 2013; N. Š. K. 2013), a ni Turističko-ugostiteljska komora Slovenije "još nije ocijenila" moguće negativne utjecaje na turizam zbog ukidanja 2. siječnja (N. Š. K. 2013), Gospodarska komora Slovenije je predložila da se u Sloveniji ukine barem još jedan državni praznik i neradni dan, npr. Velika gospa, 15. kolovoza, i/ili Dan reformacije, 31. listopada (vidi npr. N. Š. K. 2013). ${ }^{8}$

Početkom 2012. godine u slovenskoj je javnosti na najveći odjek naišao prijedlog o ukidanju 2. siječnja i 2. svibnja kao praznika i neradnih dana pri

${ }^{6}$ Slovenski kulturni praznik (8. ožujka), Dan otpora okupatoru (27. travnja), Dan državnosti (25. lipnja), Dan reformacije (31. listopada), Dan samostalnosti i jedinstva (26. prosinca) (STA 2012). Prema Zakonu o praznicima i neradnim danima (Zakon o praznikih in dela prostih dnevih) iz 1991. godine svi dani spadaju u kategoriju praznika i neradnih dana, dok Dan reformacije nije praznik nego samo neradni dan (Zakon o praznikih in dela prostih dnevih $v$ RS 1991).

${ }^{7}$ Riječ je o Danu Rudolfa Maistera (23. studenog), Danu povratka Primorske k matičnoj domovini (5. rujna) i Danu ujedinjenja prekmurskih Slovenaca s matičnim narodom (17. kolovoza) (STA 2012). Zakon o praznicima i neradnim danima iz 1991. godine koji razlikuje tri kategorije (praznike - koji su neradni dani, praznike koji su radni dani i neradne dane) još nije sadržavao te praznike (Zakon o praznikih in dela prostih dnevih $v$ RS 1991), kao praznici - neradni dani u Sloveniji poznati su tek od 2005. godine (Zakon o spremembah in dopolnitvah Zakona o praznikih in dela prostih dnevih $v$ RS 2005).

${ }^{8}$ Iako se prema zakonu zapravo ne radi o prazniku, nego o neradnom danu (Zakon o praznikih in dela prostih dnevih v RS 1991). 
čemu je prvenstveno onaj dio javnosti koji se zauzimao za njihovo ukidanje vrlo često oba dana prikazivao kao ostatke nekadašnjeg društveno-političkog uređenja i zajedničke države: ${ }^{9}$

S obzirom na to da živimo u Europi koja navodno ima kršćanske korijene, 15. kolovoza mora biti praznik, a ako ti želiš slaviti još 2 . siječnja i svibnja, možeš do Kine i ugodna proslava! (Predlagam vladi/srecni ocka 2012)

Tako je taj prijedlog postao još jedno osinje gnijezdo oko kojega se vrtio i inače podijeljeni odnos slovenske javnosti prema bliskoj prošlosti. Zbog toga se i drugi dio komentatora pitao zašto bi trebalo ukinuti baš te "socijalističke stečevine" i zašto ne bismo, ako već moramo, umjesto 2 . siječnja i/ili 2 . svibnja radije ukinuli neki drugi, primjerice vjerski, praznik, kao npr. Uskrsni ponedjeljak, koji je tek u samostalnoj Sloveniji (ponovno) postao praznik i neradni dan. ${ }^{10}$ Političko-ideološku razdvojenost javnosti prepoznali su (ili njoj još dodatno pridonijeli) i mediji koji su istodobno izvještavali o "uravnoteženom", odnosno "pravednom" ukidanju dvaju državnih i dvaju vjerskih praznika, tj. neradnih dana u Portugalu (G. V. 2012), kao i o ukidanju jednog državnog i jednog vjerskog praznika u Slovačkoj ("Na Slovaškem zahteva po umiku cerkvenih praznikov" 2012).

Pored toga, tekstovi u medijima ukazuju i na neujednačeno razumijevanje odnosa između praznika i radne produktivnosti: s jedne strane dio javnosti je praznike doživljavao kao prepreke radnom učinku, dok ih je drugi smatrao zasluženim i nužnim slobodnim vremenom za skupljanje nove (radne) energije. Kad su u travnju 2012. godine jedne od vodećih slovenskih novina Delo o tome ispitivale svoje čitatelje, većina anketiranih je odgovarala da ukidanje praznika ne povećava radnu produktivnost, a pojedinci su tome pridodali da će ljudi zbog ukidanja praznika još više mrziti svoj posao (Voh Boštic 2012). U odnosu na brojnost onih koji su prijedlog podupirali zbog ideoloških i političkih uvjerenja, znatno je manje bilo javnih komentara u kojima su se njihovi autori za prijedlog zauzimali zbog eventualnih gospodarskih razloga. Zajedno s udruženjem poslodavaca i predstavnicima Gospodarske komore Slovenije taj je dio javnosti pretpostavljao da bi ukidanje praznika osnažilo gospodarsku produktivnost države te tako doprinijelo gospodar-

${ }^{9}$ Višednevne proslave praznika, slično kao i u drugim socijalističkim državama, bile su poznate i u Titovoj Jugoslaviji (Rihtman-Auguštin 1990: 25), gdje su se već od 1949. godine po dva dana slavili Praznik rada i Dan Republike, a kao savezni državni praznik i Nova godina se, prvim poslijeratnim zakonom o državnim praznicima iz 1955. godine, slavila dva dana (Habinc 2006, usp. Gabrič 1997: 120 i Makarovič 1995: 333).

${ }^{10}$ Prema zakonu je Uskrsni ponedjeljak neradni dan (Zakon o praznikih in dela prostih dnevih $v$ RS 1991). U proljeće 2012. tada glavna opozicijska politička stranka i pojedinci predlagali su i ukidanje (prema njihovu mišljenju praznika i) neradnog dana Velike Gospe, 15. kolovoza (Perčič 2012; usp. npr. Predlagam vladi/Janez Mrgole 2012). 
skom napretku: "Ukidanje praznika može pridonijeti smanjenju troškova. ${ }^{11}$ Više radnih dana u godini će povećati bruto domaći proizvod" (Voh Boštic 2012). Prema njihovom mišljenju, smanjenje broja praznika povećalo bi broj radnih dana i smanjilo troškove poslodavaca za plaćanje nerada, a upravo je to zasmetalo sindikaliste: "Oni zakonodavci koji zahtijevaju ukidanje praznika vide radnika kao čisti trošak. Već previše ljudi radi više od deset sati na dan zbog straha da će izgubiti posao [...] ukidanjem 2 . svibnja neće biti veće plaće, no bit će veća zarada" (Voh Boštic 2012; usp. Zorc i Štok 2012).

Ukidanje praznika kao ukidanje radničkih prava, a ne kao mjeru štednje, komentirao je i urednik studentskog radija, izjavivši da jedini koji danas još mogu slaviti "praznik rada bez rada" su nezaposleni:

Prava radnika danas nestaju zajedno sa stalnim poslovima. Agencije za zapošljavanje, samostalno poduzetništvo i rad na ugovor već dugo uopće ne poznaju 2. svibnja kao neradni dan i za vrijeme radnog vremena plaćeni odmor za ručak. I zato živio 2. svibnja - Praznik rada bez rada koji će ubuduće kao neradni dan obilježavati samo još armade službeno i neslužbeno nezaposlenih po cijeloj Europi. (Zaniuk 2012)

U diskurzivnim okršajima koji ukazuju i na specifične ekonomske i poslovne uloge njihovih protagonista ukazao se i odnos državnog uređenja blagdanskog kalendara i radničkih prava, ${ }^{12}$ dok su se mediji i većina izvjestitelja u svojim komentarima usredotočili prvenstveno na obujam i kvalitetu rada u Sloveniji. Te su podatke uspoređivali s podacima za druge (prije svega zapadnoeuropske) države pri čemu je često kontradiktorna ili neobjašnjena statistika koristila kao jedno od najčešćih sredstava argumentiranja. ${ }^{13}$ Brojne su bile osude na račun "produktivnog" privatnog i "neproduktivnog" javnog sektora, koji su zbog toga i neusporedivi. Primjerice: "Kad sam još radio kod privatnika, radio sam ne samo za 'nevažne' praznike nego i sve subote i nedjelje, stalno, svaki dan, ponekad i po 12 sati i to intenzivno radio, a ne kao neki naši javni službenici koji zahtijevaju visoke plaće, neki čak i za nerad" (Genius 2012). Komentatori su se rjeđe posvećivali specifičnom radnom ri-

\footnotetext{
${ }^{11}$ Prema Zakonu o radnim odnosima (Zakon o delovnih razmerjih) poslodavac u Sloveniji radniku je dužan isplatiti naknadu za zakonom određene praznike i neradne dane, no ako radnici svejedno te dane rade, onda im osim naknade pripadaju i dodaci (usp. Belopavlovič 2003: 543-544). Drukčije rečeno radnici su plaćeni za praznike koji su ujedno i neradni dani i za zakonom određene radne dane, što znači da zakonom određeni praznici i neradni dani pridonose mjesečnoj plači pojedinca, odnosno - gledano iz drugog kuta - troškovima poslodavca.

${ }^{12}$ Rijetki komentatori su, primjerice, predlagali da se promijeni cijeli sustav i plati samo one pojedince koji praznicima zaista rade (Predlagam vladi/tanjav 2012).

${ }^{13}$ Primjerice, suprotno tvrdnjama poslodavaca, prema podacima Statističkog ureda Republike Slovenije, radnici rade skoro dva sata dnevno više od europskog prosjeka. Osim toga, radnici u Sloveniji imaju pravo na najmanje 20 dana plaćenog godišnjeg odmora što je prema podacima Statističkog ureda znatno ispod europskog prosjeka (Voh Boštic 2012).
} 
tmu pojedinih zanimanja javnih službenika: “U većini poslova javnog sektora radi se i 2. siječnja i 2. svibnja. Misli li vlada da će policajci upaliti semafore i otići na more, a da će medicinske sestre zaključati vrata bolnica i vratiti se jednom nakon praznika. Što se onda uštedi?" (Izivalka 2012). Bez obzira na polarizaciju javnosti u vezi (ne)produktivnosti javnog sektora, česta su bila upozorenja komentatora o "realnom stanju" gospodarstva, koje dva dodatna radna dana ne mogu promijeniti: "Gdje nema dovoljno narudžbi nema ni posla, a gdje ih je dovoljno tamo radnici - željeli ili ne skupljaju blagdanske prekovremene sate" (Predlagam vladi/France 2012). Možda je i zato satirični prijedlog nepoznatog autora, koji je na internetu predstavio svoj kalendar i njime pogled na očuvanje, odnosno ukidanje praznika i neradnih dana u Sloveniji, postao pravi internetski hit, koji za ilustraciju predstavljamo sljedećim citatom:

Slažem se s prijedlogom Vlade i neka se 2. siječnja kao praznik ukine. Činjenica da smo godinu dana stariji ili da nas u novoj godini čeka još gora godina nego što je bila prošla, zaista nije razlog za dvodnevno slavlje praznika. [...] 8. veljače, Prešernov dan, slovenski kulturni praznik. Taj praznik neka se ukine, jer ako smo već počeli s postupnim ukidanjem slovenske kulture tad nam nije potreban ni praznik. [...] Uskrs i uskrsni ponedjeljak. Nedjelja je neradni dan i imamo dovoljno vremena da se odmorimo i malo proslavimo Uskrs. Ponedjeljak neka bude radni dan da izgubimo nešto kalorija i tako učinimo nešto i za svoje zdravlje. (A. L. 2012)

\section{PRIJEDLOG O UKIDANJU PRAZNIKA KAO GOSPODARSKA MJERA ŠTEDNJE I ODAZIV NA NJU - PRIMJER HRVATSKE}

Gotovo istodobno, početkom 2012. godine, hrvatska je Vlada poput slovenske, zbog štednje i povećanja produktivnosti, razmatrala ukidanje triju državnih praznika i neradnih dana, koji su se svi te godine smjestili u lipnju: Dan državnosti (25. lipnja), Dan antifašističke borbe (22. lipnja) i Tijelovo. Dio javnosti ${ }^{14}$ prijedlog je, slično kao i u Sloveniji, podupirao, dok mu se drugi protivio. Pored političkih i ideoloških komentara povezanih s odnosom prema bivšoj Jugoslaviji, i u Hrvatskoj je bilo najviše onih mišljenja koja su ukazivala na odnos između posla, praznika i produktivnosti. U Hrvatskoj su, slično kao i u Sloveniji, mediji utvrđivali s pomoću statističkih podataka je li hrvatsko radno vrijeme (europski) prihvatljivo, pri čemu je velik i podijeljeni

\footnotetext{
${ }^{14}$ Rezultati jedne ankete, za ilustraciju, pokazuju da je hrvatska javnost bila podijeljena: od 16793 anketiranih njih 48\% se nije slagalo s Vladinim prijedlogom, jer "ionako previše radimo". 29\% se slagalo s prijedlogom, jer "svaka pomoć (gospodarstvu - op. a.) je dobrodošla”, dok se 23\% ispitanih doduše slagalo s Vladinim prijedlogom, iako “to nam neće puno pomoći” (Z. S. 2012).
} 
odjek izazvao prilog pod naslovom "Ukidanje praznika ne štedi novac, u EU bogati rade manje” (Špoljar 2012). Među ostalim, u tekstu se navodi da Nijemci, Francuzi i Šveđani imaju najviše godišnjeg odmora što ne smanjuje njihovu radnu produktivnost: "Naprotiv!” (Špoljar 2012). Najsnažnija europska gospodarstva (prema autoru članka) su ona s najviše neradnih dana u godini, jer dulji odmor osnažuje radnu produktivnost (Špoljar 2012; "Rade manje od drugih, a među najjačima su u svijetu"). Na to je odgovor jednog od komentatora bio: "Iz gornje tablice ispada, kako nam treba još jedan praznik i živjet ćemo kao u Luxemburgu” (jolly 2012; usp. stefi 2012). ${ }^{15}$ Slično kao i u Sloveniji, i u Hrvatskoj su se rijetki pojedinci zaustavljali kod sustavnih pitanja, primjerice plaćanja rada za praznik i neradni dan (vidi npr. bomba 2012), a mnogi su komentatori isto tako posumnjali u produktivnost javnog sektora (stefi 2012, usp. piranha2 2012). Uz to, pojedini su se komentatori okomili i na dijelove Hrvatske u kojima ljudi navodno rade manje nego drugdje: "kod naših dalmoša i istrijana - i oni rade 2 mjeseca a onda imaju 10 mjeseci dopusta" (robert333 2012).

Bez obzira na to jesu li komentatori podupirali ukidanje praznika ili ne, slično kao u Sloveniji, većina nije povezivala radnu produktivnost s, primjerice, brojem neradnih dana, zanimanjem ili životnim prostorom, nego prije svega s mentalitetom. Ukidanje triju praznika komentatori su često vidjeli kao "ukidanje neradničkog mentaliteta" ${ }^{16}$ te mjeru protiv "kulta nerada" kao ostatka socijalizma: "Produktivnost se mjeri ne provedenim vremenom na poslu nego konačnim rezultatom toga posla. Shodno tomu kod nas u Hrvatskoj je produktivnost vrlo niska pa kad još imaš toliko neradnih dana dobiješ to što sad imamo. Kult nerada" (EUfan 2012). ${ }^{17}$ Prema takvim su komentarima europske države bogate "jer imaju vrednije radnike [...] U onoj staroj (državi, Jugoslaviji - op. a.) radnici su imali poslovicu koja je glasila: 'ne može on mene toliko malo platiti koliko ja mogu malo raditi.' Nažalost neki su ostali vjerni toj staroj poslovici" (japa 2012). Takav neradnički "duh socijalizma” još uvijek navodno omogućuje i “socijalističko" spajanje praznika i slobodnih dana u kratki godišnji odmor (vidi npr. fluid 2012, merjan 2012, piranha2 2012). ${ }^{18}$

${ }^{15}$ Svi naslovi i citati (osim slovenskih) u članku nisu (jezično) korigirani (ili prevedeni).

${ }^{16}$ Primjerice: "Ljudi u ovoj državi trebaju shvatit da se plače zaradjuju a ne poklanjaju. [...] Ukidanje nepotrebnih praznika u svakom slučaju je potriba i poruka dosta je p***rija i nerada. Ko misli drugčije je isto tako neradnik i linčina" (merjan 2012).

${ }^{17}$ Usp. i: "Nije problem u praznicima. Hr ih može imati i 20, no bitno je da Hrvati kad dodju na radno mjesto rade, toga očito fali. Produktivnost je bitna, a ne RADIO NE RADIO DAN PRODJE” (GERO2 2012).

${ }^{18}$ Spajanje praznika i slobodnih dana kritizirali su prvenstveno oni koji su se zauzimali za ukidanje triju praznika, ali je, primjerice, predsjednik Neovisnih sindikata Hrvatske negirao da se radi o "hrvatskom izumu" jer "Zapadne države čak potiču radnike da spajaju dane, organiziraju kolektivne odmore i slično, samo da bi radnik imao više odmora i samim time elana, a to rezultira većom produktivnošću" (Deželić 2012). Kao i u Sloveniji, tu i tamo pojavljivala su se i upozorenja da spajanje nije opća praksa jer su iz nje izuzeti brojni zaposlenici u javnom sektoru kao što su prometnici, policajci, liječnici i medicinske sestre. 
S druge strane, slično kao i u Sloveniji, drugom dijelu javnosti ideja o općoj neproduktivnosti nije bila bliska, jer "u državi gdje je skoro 400000 ljudi nezaposleno oni brinu za produktivnost" (piranha2 2012). Ili: "Baš bih vas volio vidjeti kako biste vi bili produktivni kada biste radili po desetak sati dnevno, živite kao podstanari, a plaća vam kasni po nekoliko mjeseci" (Ivica6 2012, usp. piranha2 2012). Ukidanje praznika tako bi, slično kao što su to barem sindikalisti i pojedinci vidjeli i u Sloveniji, u prvom redu koristilo poslodavcima. Zanimljivo je i to da se skoro bez odaziva, ali približno istodobno, u hrvatskoj javnosti pojavio i prijedlog turističkih djelatnika Gorskog Kotara koji su se zbog koristi za turizam zauzimali za to da se nakon Nove godine, po uzoru na nekadašnju Jugoslaviju i suvremenu Sloveniju ${ }^{19}$ i Srbiju, 2. siječanj ponovno doda kao drugi blagdanski i neradni dan:

\begin{abstract}
"Jedan dan više za Novu godinu u praksi znači da se novogodišnji blagdani produžuju na minimalno četiri dana. Ako, na primjer, Nova godina padne u srijedu, onda je i četvrtak slobodan, a ljudi bi spojili još i petak i imate petodnevni aranžman", pojasnio je za Novi list Marinko Jakovljević, direktor Turističke zajednice općine Fužine. ("Vratite nam 2. siječnja kao neradni dan" 2012, usp. M. B. 2012)
\end{abstract}

No, slično kao i prijedlog o ukidanju triju praznika, i ideja o ponovnom uvođenju 2. siječnja kao praznika i neradnog dana ostala je samo na papiru. Naime, u travnju 2012. hrvatska je Vlada objavila da se praznici ne ukidaju, jer bi ta mjera, prema njihovim ocjenama, upravo turizmu, kao značajnoj gospodarskoj grani, prouzrokovala više štete nego koristi ("Vlada još neće ukinuti lipanjske blagdane" 2012).

\title{
UKIDANJE PRAZNIKA KAO GOSPODARSKO RJEŠENJE ILI PITANJE IDENTITETA?
}

Od kraja svibnja 2012. godine kad je u Sloveniji donesen Zakon o uravnoteženju javnih financija skoro nije bilo odaziva na ukidanje 2. siječnja, a slični, mada znatno rjeđi komentari o ukidanju još kojeg praznika i/ili neradnog dana pojavili su se ponovo 2013. godine. Očuvanjem 2. svibnja (ali ne i 2. siječnja) u Sloveniji je radu bilo očuvano simbolično značenje - koje, doduše, s radničkom svakodnevicom baš i nema puno veze - dok u Hrvatskoj ni jedan praznik zbog rada, tj. zbog predviđene gospodarske koristi od praznika nije bio ukinut. Zanimljivo je da su razmišljanja obiju Vlada o ukidanju praznika potakla većinom dvije vrste komentara: o povezanosti praznika s marljivošću

${ }^{19}$ Tada je Slovenija 2. siječnja još uvijek poznavala kao praznik i neradni dan. 
i o tome koje praznike i uz njih vezane identitete eventualno treba ukinuti. Iako je to, navodno, bio glavni razlog za prijedloge (i njihovu realizaciju), prema mišljenju većine komentatora praznici baš i nemaju puno veze $s$ mogućim poboljšanjem gospodarske situacije. Možda se zbog toga službeni, a i većina neslužbenih diskursa nije toliko fokusirala na sustavno uređenje plaćanja rada za praznike (i/ili neradne dane) i radnička prava, nego se znatno više zaustavljala na mentalitetu i identitetu navodno vezanim uz pojedine praznike, odnosno općenito za marljivost, pri čemu se mahom približavanje Europi pokazalo kao cilj predloženih (i/ili realiziranih) promjena. S pomoću donesenog "kompromisnog" rješenja koje čuva, kao praznik i neradni dan, simbolično važniji 2. svibanj, kako je objasnila Vlada, Slovenija se navodno sada još više može usporediti s kršćanskom Europom:

\begin{abstract}
Uzimajući u obzir strukturu praznika u europskim državama, možemo utvrditi da je u većini država s kojima se Slovenija uspoređuje, većina praznika vjerskih, a osim Nove godine i Praznika rada njihovo je obilježavanje vezano još uz državnost pojedinih država [...] potrebno je naglasiti da dvodnevne proslave Nove godine nisu usustavljene u većini evropskih država s kojima se Slovenija uspoređuje [...] Ovo navedeno će na kraju imati pozitivan utjecaj na konkurentnost slovenskog gospodarstva i mogućnost uspoređivanja sustava neradnih dana s državama Europske unije. (Odziv Ministarstva za delo, družino in socialne zadeve 2012)
\end{abstract}

Iz navedenog se može vidjeti da diskursi vezani za ukidanje praznika u Sloveniji i u Hrvatskoj mahom odražavaju i predodžbe o tome što je više ili manje "europsko", postavljajući time ujedno i temeljni analitički cilj koji nam ovdje valja pratiti. Što se usput (barem u Sloveniji) dogodilo s prvotnim Vladinim ciljem da se ukidanjem praznika poboljša produktivnost i gospodarska situacija ostaje nejasno: ako mjera već ne koristi toliko gospodarstvu, može barem pridonijeti promijenjenoj identifikaciji društva. Analizirani diskursi ukazuju na to da se "mentalno mapiranje" i "simbolična geografija" predodžbi, prema kojima Balkan još nije Europa (usp. Đerić 2005: 148), još uvijek uspješno udomaćuju i zbog samopripisivanja "socijalističkog neradničkog mentaliteta". Proces "stvaranja Drugog", koji su zapadni istraživači postsocijalizma već napustili, tako se, paradoksalno, reproducira kao "unutrašnji orijentalizam" (Prica 2007: 176) koji služi razlikovanju lijene, socijalističkim neradničkim mentalitetom još uvijek obilježene većine radnika i trans-ideološke "sposobne društvene elite" koja želi razvoj u pravcu Europe (isto: 178$){ }^{20}$

\footnotetext{
${ }^{20}$ Takva podjela, čini se, ima svog prethodnika u unutrašnjem razlikovanju više ili manje vrijednih radnika u socijalističkoj Jugoslaviji. Djelomice slično kao i danas odnosilo se na vrjednije, prema Zapadu usmjerene sjevernije republike i na drugoj strani njihov navodni kontrast u južnim, ljenjim predjelima tada zajedničke države (vidi npr. Erdei 2009).
} 
Stoga se jednim od najvažnijih ciljeva ukidanja praznika prikazivala okolnost da (ma kako se došlo do te statistike) ${ }^{21}$ država po broju praznika i neradnih dana ne odstupa od europskog prosjeka, a kao "više ili manje europski" bio je, pored broja praznika, prepoznat i način njihove proslave, odnosno ograničenost proslave na samo jedan dan. Tako država može imati praznika i neradnih dana "još manje od europskog prosjeka", ali je u njezinoj "neeuropskosti" mogu odavati višednevne proslave praznika koje radnici povezuju sa slobodnim danima u kraći godišnji odmor, što su komentatori najčešće shvatili kao "relikt socijalizma".

Dakle, ako domaće ogorčeno bavljenje socijalističkim mentalitetom (usp. Prica 2007: 176) i njegovo pozicioniranje u društvenoj i političkoj sferi ne shvatimo kao nešto nevažno, granično i bizarno, nego kao simbol aktualnih odnosa moći, onda je važno analizirati i kada (i kako) se određeno karakteriziranje uopće upotrebljava (Đerić 2005: 86). Sudeći prema sažetoj građi, predodžba o "tradiciji socijalističkog neradničkog mentaliteta" - kao i svaka druga predodžba o tradiciji - koristi se uglavnom za homogeniziranje zajednice i utvrđivanje njezinih (prvenstveno geografskih) granica, u ovom slučaju temeljno ocrtanih samokritikom, ${ }^{22}$ internaliziranim osjećajem Drugosti i iskustvima nezadovoljstva. ${ }^{23}$ Prema Đerić, postoje brojni slučajevi koji pokazuju da se rasprave o "značajnosti nacionalnog karaktera i identiteta" u javnosti pokreću kako bi se pomoću njih rješavala teža socijalna ili povijesna pitanja (Đerić 2005: 141 i 49). Ustrajanje na psihološkim konstantama "nacionalnog karaktera" namijenjeno je naglašavanju statičnosti, koja vodi prema izjednačavanju i zamjenjivosti provjerljivog neprovjerljivim, vidljivog nevidljivim, predmetnog idejnim. Karakterološkim oznakama kolektiva trebali bismo oblikovati samo doživljavanje realnog: zamišljeno se manifestira kao "realno", a završava kao trajna oznaka "sudbine" kolektiva i posredno svakog pojedinca koji mu pripada (Đerić 2005: 85-86). Problem nabrajanja, opravdavanja, slavljenja i kritiziranja pojedinih "osobina nacionalnih značajki" ni Đerić ne vidi samo u trajnoj egzotizaciji i psihologizaciji društvenih pojava - radi se, prije svega, o racionalnim izgovorima koji mogu proizvesti (političke) argumente. Kod objašnjavanja pojava, čiji su razlozi zapravo

\footnotetext{
${ }^{21}$ Primjerice, ako se određeni praznik slavi više (ili dva) dana, to se u zbrajanju praznika i nije moralo uzimati u obzir, no isto tako mogli su se uzimati u obzir samo praznici-neradni dani, a ne i kategorija neradni dani. Više o pravnoj hijerarhiji praznika u Srednjoj i Jugoistočnoj Europi u Gammelgaard i Šarić (2012: 14).

${ }^{22}$ Kao što je već ustanovila Đerić, svakodnevne diskurzivne prakse negiraju prevladavajući akademski stereotip prema kojem pripadnici nekog naroda imaju isključivo pozitivnu sliku o sebi, dok o drugima zadržavaju prvenstveno negativnu sliku. Opet se, naime, pokazalo baš suprotno. Prevladavaju upravo negativni i/ili samokritični autostereotipovi, među njima i oni vezani za nerad (usp. Prica 2007: 166 i Đerić 2005: 129-131).

${ }^{23}$ Kao što je to ustanovio i Marković, sjećanja na rad u socijalizmu bila su pozitivnija prije nekoliko desetljeća nego danas, što odražava i razočaranje suvremenom radničkom situacijom (Marković 2007: 34).
} 
interesni, ekonomski, geostrateški, ideološki ili povijesni, odlučujući mogu postati specifični mentaliteti i iracionalni razlozi - a svi ostali su izuzeti i potisnuti na rub (Đerić 2005: 85-86). Negiranje racionalnih mogućnosti nositelja preživjelog socijalističkog mentaliteta, prema Prici, vodi do neracionalnog obrazloženja suvremene krize (2007: 170) koje zamagljuje i društvenu i osobnu odgovornost za nju.

Sve se to, kako se pokazalo, može izlučiti i iz rasprava o ukidanju praznika. Potaknule su (iracionalnu) političku argumentaciju prema kojoj će samo simboličko udaljavanje od socijalizma i približavanje (kršćanskoj) Europi pridonositi gospodarskom unapređenju. Značajni razlozi za recesiju u mnogim se komentarima tako ne identificiraju kao racionalni, bilo interesni, ekonomski i geostrateški, nego je navodno u pitanju specifični, socijalistički mentalitet (i identitet), koji treba promijeniti pa će se (možda?) promijeniti i produktivnost i općenito poboljšati gospodarstvo. Ako Vladini politički prijedlozi i ukazuju na to da za mijenjanje "mentaliteta" valja primijeniti i neka sustavna rešenja - ostaje da nije bilo racionalnih i produbljenih rasprava o tome o kojim bi to se rješenjima radilo. Jednako tako, nisu postojala sustavna preispitivanja plaćanja rada za praznike (i/ili neradne dane) ili specifičnosti pojedinih zanimanja, nego se vodila diskusija o općenitom "rješenju": praznici da ili ne, koje i koliko njih slaviti. Pri takvoj usredotočenosti na sustavna pitanja, gdje je odnos između marljivosti i praznika jednoznačan, kao racionalni oslonac poslužila je Europa, a kao njezin (kulturno) iracionalni antipod u prvom je redu prepoznat prežitak socijalističkog društvenog uređenja. Europa, koja jest politički i gospodarski nadređena Sloveniji (a za vrijeme rasprava Hrvatska je to tek priželjkivala), tako barem za vlade i trans-ideološke "sposobne društvene elite" ostaje neupitan politički i gospodarski racionalni oslonac, pri čemu je pitanje na što se konkretno u cjelini te "europskosti" osloniti prepušteno pojedinim zemljama, odnosno njihovim političkim i drugim akterima. Iako su sindikalni i neslužbeni diskursi često posumnjali u gospodarsku korist od ukidanja praznika to, makar u Sloveniji, nije preusmjerilo službena razmišljanja prema nekom drugom pravcu sustavnih promjena. Iracionalni razlozi savladali su tako političku argumentaciju barem na dva načina: uvažavanjem prvenstveno mentaliteta, a ne interesnih, ekonomskih, geostrateških, ideoloških ili povijesnih razloga kao ključnih za gospodarsku krizu, i razumijevanjem Europe kao puta prema racionalnosti per se. 


\section{NAVEDENA LITERATURA I IZVORI}

A. L. 2012. "Predlog vladi glede ukinitve praznikov". Dostupno na: http://www.zurnal24.si/ predlog-vladi-glede-ukinitve-praznikov-clanek-152740 (pristup 26. 6. 2012.).

Baš, Franjo. 1965. "O karakterologiji prebivalstva v štajerskem Podravju”. Časopis za zgodovino in narodopisje 1: 163-175.

Belopavlovič, Nataša i dr. 2003. Zakon o delovnih razmerjih s komentarjem. Ljubljana: GV založba.

bomba. 2012. Dostupno na: http://www.vecernji.hr/vijesti/ukidanje-praznika-ne-stedi-novac-eu-bogati-rade-manje-clanak-376235 (pristup 16. 8. 2013.).

Borko Grimšič, Manca. 2013. "V gospodarstvu bi še ukinjali praznike”. Dostupno na: http:// www.zurnal24.si/v-gospodarstvu-bi-se-ukinjalistroski-nizji-v-javnem-sektorjuv-sempetru-grozil-z-bmboquit-ocus-clanek-181551 (pristup 16. 8. 2013.).

Deželić, Vanja. 2012. “Treba li Vlada ukinuti koji od 14 neradnih dana u godini?” Dostupno na: http://www.politikaplus.com/novost/66961/treba-li-vlada-ukinuti-koji-od-14-neradnih-dana-u-godini (pristup 16. 8. 2013.).

Đerić, Gordana. 2005. Pr(a)vo lice množine. Kolektivno samopoimanje i predstavljanje: mitovi, karakteri, mentalne mape i stereotipi. Beograd: Institut za filozofiju i društvenu teoriju.

Erdei, Ildiko. 2009. "Za tango je potrebno dvoje. Ekonomija i identiteti Srba i Slovenaca u postsocijalizmu". Dostupno na: http://pescanik.net/za-tango-je-potrebno-dvoje/ (pristup 24. 8. 2015.).

EUfan. 2012. Dostupno na: http://www.vecernji.hr/vijesti/ukidanje-praznika-ne-stedi-novac-eu-bogati-rade-manje-clanak-376235 (pristup 16. 8. 2013.).

fluid. 2012. Dostupno na: http://www.nacional.hr/clanak/124817/vlada-zbog-stednje-ukida-drzavne-praznike (pristup 16. 8. 2013.).

Gabrič, Aleš. 1997. "Ponekod pa je bila izvedena novoletna jelka šele na intervencijo tamkajšnjih komitejev partije". U Historični seminar, 2. Oto Luthar i Vojislav Likar, ur. Ljubljana: Založba ZRC SAZU, 109-121.

Gammelgaard, Karen i Liljana Šarić. 2012. "Discursive Construction of National Holidays in West and South Slavic Countries after the Fall of Communism". U Transforming National Holidays. Identity, Discourse in the West and South Slavic Countries, 1985-2010. Karen Gammelgaard, Liljana Šarić i Kjetil Rå Hauge, ur. Amsterdam: John Benjamins, 5-31.

Genius. 2012. Dostupno na: http://www.zurnal24.si/predlog-vladi-glede-ukinitve-praznikov-clanek-152740 (pristup 26. 6. 2012.).

GER02. 2012. Dostupno na: http://www.vecernji.hr/vijesti/ukidanje-praznika-ne-stedi-novac-eu-bogati-rade-manje-clanak-376235 (pristup 16. 8. 2013.).

G. V. 2012. "Portugalci pravično porazdelili ukinitev praznikov - dva verska in dva državna". Dostupno na: http://www.rtvslo.si/svet/portugalci-pravicno-porazdelili-ukinitev-praznikov-dva-verska-in-dva-drzavna/282747 (pristup 26. 6. 2012.).

Habinc, Mateja. 2006. Posledice spreminjanja prazničnega koledarja v načinu življenja Brežičanov. [neobjavljena doktorska disertacija]. Ljubljana: Filozofska fakulteta, Oddelek za etnologijo in kulturno antropologijo.

Hine, Christine. 2004. "Virtualni predmeti etnografije". U Etnografije interneta. Iva Pleše i Reana Senjković, ur. Zagreb: Institut za etnologiju i folkloristiku, 27-54.

Ivica6. 2012. Dostupno na: http://www.vecernji.hr/vijesti/ukidanje-praznika-ne-stedi-novac-eu-bogati-rade-manje-clanak-376235 (pristup 16. 8. 2013.). 
Izivalka. 2012. Dostupno na: http://kupid.com/forum/_vt.php?t=27441 (pristup 26. 6 . 2012.).

japa. 2012. Dostupno na: http://www.vecernji.hr/vijesti/ukidanje-praznika-ne-stedi-novaceu-bogati-rade-manje-clanak-376235 (pristup 16. 8. 2013.).

Jezernik, Božidar. 1987. “O kolektivnih karakterizacijah”. Traditiones 16: 29-34.

jolly. 2012. Dostupno na: http://www.vecernji.hr/vijesti/ukidanje-praznika-ne-stedi-novaceu-bogati-rade-manje-clanak-376235 (pristup 16. 8. 2013.).

Kiossev, Alexander. 1999. "Notes on Self-colonising Cultures". U Art and Culture in Postcommunist Europe. Bojana Pejić i David Elliott, ur. Stockholm: Moderna Museet, 114-118.

M. B. 2012. "Recesija grize i blagdane". Dostupno na: http://www.tportal.hr/vijesti/hrvatska/175569/Linic-za-a-Komadina-protiv-ukidanja-neradnih-dana.html (pristup 16. 8. 2013.).

Makarovič, Gorazd. 1995. Slovenci in čas. Odnos do časa kot okvir in sestavina vsakdanjega življenja. Ljubljana: Krtina.

Melegh, Attila. 2006. On the East-West Slope. Globalization, Nationalism, Racism and Discourses on Central and Eastern Europe. Budapest, New York: CEU Press.

Marković, Predrag J. 2007. "Sećanja na rad u jugoslovenskom socializmu između kritike i mita o zemlji Dembeliji”. U Predrag J. Marković. Trajnost i promena. Društvena istorija socijalističke i postsocijalističke svakodnevice u Jugoslaviji i Srbiji. Beograd: Službeni glasnik, 27-41.

merjan. 2012. Dostupno na: http://www.slobodnadalmacija.hr/Hrvatska/tabid/66/articleType/ArticleView/articleId/163961/Default.aspx (pristup 16. 8. 2013.).

"Na Slovaškem zahteva po umiku cerkvenih praznikov". 2012. Dostupno na: http://www.druzina.si/icd/spletnastran.nsf/all/0C2A805B17C3AD3AC1257A30004C92D1?OpenDocum ent (pristup 16. 8. 2013.).

Novak, Vilko. 1986. Raziskovalci slovenskega življenja. Ljubljana: Cankarjeva založba.

N. Š. K. 2013. “Semolič. Ukinjanje praznikov je zgrešen ukrep”. Dostupno na: http://www.24ur. com/novice/slovenija/bomo-ostali-se-brez-enega-praznika.html (pristup 16. 8. 2013.).

Obad, Orlanda. 2012. "Europljani poput nas. Društvena percepcija Europske unije u Hrvatskoj". Autsajderski fragmenti 7/14: 7-47.

"Odziv Ministrstva za delo, družino in socialne zadeve". 2012. Dostupno na: http://predlagam. vladi.si/webroot/idea/view/3102/null/answers/ (pristup 26. 6. 2012.).

Perčič, Aleš. 2012. "Jankovićevi bi ukinili Marijino vnebovzetje”. Dostupno na: http://www. finance.si/351847/Jankovi\%C4\%87evi-bi-ukinili-praznik-Marijinega-vnebovzetja (pristup 16. 8. 2013.).

piranha2. 2012. Dostupno na: http://www.vecernji.hr/vijesti/ukidanje-praznika-ne-stedinovac-eu-bogati-rade-manje-clanak-376235 (pristup 16. 8. 2013.).

Predlagam vladi/France. 2012. Dostupno na: http://predlagam.vladi.si/webroot/idea/ view/2830/null/comments (pristup 26. 6. 2012.).

Predlagam vladi/Janez Mrgole. 2012. Dostupno na: http://predlagam.vladi.si/webroot/idea/ view/3102/null/answers/ (pristup 26. 6. 2012.).

Predlagam vladi/srecni ocka. 2012. Dostupno na: http://predlagam.vladi.si/webroot/idea/ view/3102/null/answers/ (pristup 26. 6. 2012.).

Predlagam vladi/tanjav. 2012. Dostupno na: http://predlagam.vladi.si/webroot/idea/ view/2830/null/comments\%20France,\%2020.\%204.\%202012 (pristup 26. 6. 2012.).

Prica, Ines. 2007. "In Search of Post-socialist Subject". Narodna umjetnost 44/1: 163-186. 
"Rade manje od drugih, a među najjačima su u svijetu". 2012. Dostupno na: http://danas.net. hr/hrvatska/veci-broj-neradnih-dana-ne-cini-ekonomiju-slabijom (pristup 16. 8. 2013.).

Ramšak, Mojca. 2007. "Ali je teren za zaslonom mogoč? Epistemološki premisleki o spletni etnologiji". Glasnik SED 47/1-2: 20-23.

Rihtman-Auguštin, Dunja. 1990. "Metamorfoza socialističkih praznika”. Narodna umjetnost 27: 21-32.

Rihtman-Auguštin, Dunja. 1997. “Zašto i otkad se grozimo Balkana?” Erasmus 19: 27-35.

robert333. 2012. Dostupno na: http://www.vecernji.hr/vijesti/ukidanje-praznika-ne-stedinovac-eu-bogati-rade-manje-clanak-376235 (pristup 16. 8. 2013.).

STA. 2012. "Denarja le za dve državni proslavi”. Dostupno na: http://reporter.si/slovenija/ denarja-le-za-dve-dr\%C5\%BEavni-proslavi/8606 (pristup 16. 8. 2013.).

stefi. 2012. Dostupno na: http://www.vecernji.hr/vijesti/ukidanje-praznika-ne-stedi-novaceu-bogati-rade-manje-clanak-376235 (pristup 16. 8. 2013.).

Špoljar, Marko. 2012. "Ukidanje praznika ne štedi novac, u EU bogati rade manje". Dostupno na: http://www.vecernji.hr/vijesti/ukidanje-praznika-ne-stedi-novac-eu-bogati-rade-manjeclanak-376235 (pristup 16. 8. 2013.).

Todorova, Maria. 1999. “The Balkans. From Discovery to Invention”. Slavic Review 53/2: 453482. [http://dx.doi.org/10.2307/2501301]

Todorova, Maria. 2010. Imagining the Balkans. Oxford: Oxford University Press.

Trstenjak, Anton. 1991. Misli o slovenskem človeku. Ljubljana: Založništvo slovenske knjige.

"Vlada još neće ukinuti lipanjske blagdane". 2012. Dostupno na: http://www.tportal. hr/vijesti/hrvatska/186481/Vlada-jos-nece-ukinuti-lipanjske-blagdane.html?utm source=clanci\&utm_medium=manual3\&utm_campaign=clanci_manual (pristup 16. 8. 2013.).

Voh Boštic, Anže. 2012. "Anketa: Se strinjate s predlogom o odpravi 2. januarja in 2. maja kot dela prostih dni?" Dostupno na: http://www.delo.si/novice/slovenija/anketa-se-strinjate-s-predlogom-o-odpravi-2-januarja-in-2-maja-kot-dela-prostih-dni.html (pristup 26. 6. 2012.).

"Vratite nam 2. siječnja kao neradni dan". 2012. Dostupno na: http://www.tportal.hr/biznis/gospodarstvo/168249/Vratite-nam-2-sijecnja-kao-neradi-dan.html?utm_source=clanci\&utm_ medium=manual4\&utm_campaign=clanci_manual (pristup 16. 8. 2013.).

Wittel, Andreas. 2004. "Etnografija u pokretu. Od terena do mreže i interneta”. U Etnografije interneta. Iva Pleše i Reana Senjković, ur. Zagreb: Institut za etnologiju i folkloristiku, 17-25.

Wodak, Ruth. 2006. "Discourse-Analytic and Socio-Linguistic Approaches to the Study of Nation(alism)". U The SAGE Handbook of Nations and Nationalism. Gerard Delanty i Krishan Kumar, ur. London: Sage Publications, 104-117. [http://dx.doi. org/10.4135/9781848608061.n10]

Zakon o praznikih in dela prostih dnevih $v$ RS. 1991. Uradni list RS 1/26.

Zakon o spremembah in dopolnitvah Zakona o praznikih in dela prostih dnevih v RS. 2005. Uradni list RS 15/91.

Zakon o uravnoteženju javnih financ. 2012. Uradni list RS 22/40.

Zaniuk, Tomaž. 2012. "Živel 2. maj - praznik dela brez dela". Dostupno na: http://rs.hehe. si/politika/n-euro-moment/\%C5\%BEivel-2-maj-praznik-dela-brez-dela (pristup 26. 6. 2012.). 
Zorc, Damjan i Katja Štok. 2012. "Ukinjanje praznikov. Plače ne bodo višje, dobički pač”. Dostupno na: http://www.val202.si/2012/05/ukinjanje-2-januarja-in-2-maja/ (pristup 26. 6. 2012.).

Z. S. 2012. "Slažete li se da Vlada u borbi protiv krize treba ukinuti tri neradna dana?" Dostupno na: http://danas.net.hr/novac/hoce-li-nam-pomoci-ukidanje-neradnih-dana (pristup: 16. 8. 2013.).

\title{
THE EUROPEAN CHARACTER OF ELIMINATING HOLIDAYS AND THE SOCIALIST INDOLENT MENTALITY
}

\begin{abstract}
SUMMARY
The article analyses official and unofficial discourses (media reports, web commentaries and forums) in Slovenia and Croatia which deal with eliminating holidays as a part of austerity measures. It focuses on the relationship between eliminating holidays, diligence and mentality on the one hand and Balkan, socialist and European identity on the other. The analysed material suggests that both governments' proposals to eliminate holidays largely triggered two kinds of commentaries: how holidays are related to diligence and which holidays and identities related to them - if any at all - should be eliminated. If most unofficial discourses have not connected holidays with diligence and productivity, they have also not focused on systemic solutions regarding payment of work for holidays (and/or days free of work) nor have they concentrated on workers' rights. However the majority of commentaries touched upon the question of the socialist mentality and identity, which were seen as related to specific holidays. In the end, it was not productivity but rather drawing closer to Europe that appeared as a goal of the suggested (and/or realised) systemic changes.
\end{abstract}

Keywords: holidays, austerity, mentality, former Yugoslavia, (post)socialism 